\section{Infrared spectroscopic characterization, free radical scavenging and cytotoxic evaluation of chitosan extracted from Penaeus monodon shells}

Sanchita Sharmin Chowdhury ${ }^{1}$, Md. Al-Amin ${ }^{1}$, Mariam Jamila ${ }^{2}$, Samiul Haque ${ }^{3}$ Taksim Ahmed ${ }^{3}$ and Mohammed Ehsanul Hoque Mazumder ${ }^{3^{*}}$

Department of Pharmacy, Primeasia University, Dhaka, Bangladesh ${ }^{1}$ Department of Pharmacy, Bangladesh University, Dhaka, Bangladesh ${ }^{2}$ Department of Pharmacy, Jahangirnagar University, Dhaka, Bangladesh ${ }^{3}$
*Corresponding Author

Md. Ehsanul Hoque Mazumder

Assistant Professor

Department of Pharmacy

Jahangirnagar University

Savar, Dhaka-1342, Bangladesh

Contact no.: +88028913836

E-mail: munnapharmacy@yahoo.com

Received- 25 April, 2009

Accepted for Publication- 10 July, 2009

\begin{abstract}
Chitosans are naturally occurring biologically safe and non-toxic polymer of polysaccharides. In the present study, Chitosan [(1-4) 2-amino-2-deoxy- $\beta$-D-glucan] was extracted from the exoskeleton of Black Tiger (Penaeus monodon) shrimp shells by alkaline deacetylation of chitin. Three different chitosan extracts, coded as Chito A (3.33\% w/w), Chito B $(4.01 \% \mathrm{w} / \mathrm{w})$ and Chito C $(3.45 \% \mathrm{w} / \mathrm{w})$ were extracted using $3 \%, 4 \%$ and $5 \% \mathrm{w} / \mathrm{v}$ concentrations of $\mathrm{HCl}$ as decalcifiers respectively. Physicochemical properties such as appearance, odor, insolubility and $\mathrm{pH}$ of all the extracts were found to comply with the compendial specifications of pharmaceutical grade chitosan. Qualitative identification of the samples was carried out using Infrared (IR) spectroscopy. Major peaks of the extracts matched with reference IR spectrum of standard chitosan. Extracted chitosans were found lacking cytotoxicity in brine shrimp lethality bioassay. All the extracts showed strong antioxidant activity in DPPH free radical scavenging assay and the $\mathrm{IC}_{50}$ values were found to be $37 \pm 2$ $\mu \mathrm{g} / \mathrm{mL}$ (Chito A), $35 \pm 1 \mu \mathrm{g} / \mathrm{mL}$ (Chito B) and $30 \pm 2 \mu \mathrm{g} / \mathrm{mL}$ (Chito C) while the standard antioxidant Quercetin showed an $\mathrm{IC}_{50}$ value of $15 \pm 2 \mu \mathrm{g} / \mathrm{mL}$.
\end{abstract}

Key words: Chitosan, Black Tiger (Penaeus monodon) shrimp shells, deacetylation of chitin, IR spectroscopy, cytotoxicity, DPPH, free radical scavenging.

\title{
INTRODUCTION
}

Chitosan obtained from the de- $\mathrm{N}$-acetylation of chitin, is a co-polymer of $\mathrm{N}$-acetyl-glucosamine and $\mathrm{N}$-glucosamine units linked by $\beta$ - $(1 \rightarrow 4)$ glycosidic bonds, in the presence of hot alkali (Shi et al., 2006). Chitosan and its derivatives are undisputed biomolecules of great potential by their polyelectrolite properties, including the presence of reactive functional groups, gel-forming ability, high adsorption capacity, complete biodegradability, and biocompatibility (Shahidi et al., 2005). Owing to these unique properties, chitosan and its derivatives have found profound applications in food, agriculture, cosmetic, textile, pharmaceutical, biotechnological, and biomedical fields. Recent studies further indicated that chitosan and its derivatives are novel scaffold materials for tissue engineering and are-promising non-viral vectors for gene delivery (Shi et al., 2006). Chitosan has been reported to possess antidiabetic (Lee et al., 2003), antioxidant (Yen et al., 2008), hypocholesteromic (Sugano et al., 1990), immuno-enhancing (Suzuki et al., 1986a), woundhealing (Paul and Sharma 2004), hemostatic (Farkas, 1990; Fleet and Phaff, 1981), antitumor (Suzuki et al., 1986a), antimutagenic activity (Shon et al., 2001), bacteriostatic and fungistatic actions (Shahidi 2005). Pharmaceutically chitosan has the reputation of being used as a unique excipient. Due to its mucoadhesive nature chitosan exerts binding, disintegrating, and tablet coating properties (Lehr et al., 1992; Felt et al., 1999). It is used as beads, microspheres, and microcapsules typically for controlled release of drugs, proteins and DNA (Qing et al., 2007). Chitosans have been extracted from various sources such as shell wastes of shrimp, crab, lobster, krill, silkworm and squid in many countries of the world. In an earlier work, we reported (Chowdhury et al., 2008) the extraction and characterization of chitosan from the exoskeleton of local crabs (Scylla serrata). Literature search reveals that chitin and chitosan were previously extracted in Bangladesh from Hariana (Metapenaeus monoceros) shrimp shell (Naznin, 2005). In the course of our interest in exploring chitosan-extraction from local sources we herein report the extraction, infrared spectroscopic characterization, free radical scavenging and cytotoxic evaluation of chitosan extracted from Black Tiger (Penaeus monodon) shrimp shells of Bangladesh. 


\section{MATERIALS AND METHODS}

\section{Collection of shrimp samples}

Some dried tail parts of black tiger shrimps were collected from Chittagong sea port fish market area. The outer shells were separated, cleaned, dried and was grinded in to powders. $150 \mathrm{gm}$ of grinded shell waste powder was taken for extraction of chitosan.

\section{Extraction of Chitosan}

Chitosan was extracted by alkaline $\mathrm{N}$-deacetylation of chitin by slightly modifying the method described by Hirano (1996). $150 \mathrm{gm}$ of grinded shrimp shells were properly washed with water \& filtered. Then $3 \% \mathrm{HCl}$ was slowly added and kept for six hours for decalcification of the sample followed by filtration of the samples with cotton filter. After filtration, $500 \mathrm{ml} 3 \% \mathrm{NaOH}$ was added in each beaker and stirred with glass rod and kept over night at room temperature. Each sample was filtered with cotton filter and $0.5 \%$ potassium permanganate and $0.5 \%$ oxalic acid was added for decolarization. First $0.5 \%$ of potassium permanganate was added into the sample and stirred and kept for one hour followed by filtration with cotton filter. Then $0.5 \%$ of oxalic acid was added into the samples. The sample was stirred and kept for one hour at room temperature and then filtered. The above process is repeated for another two samples of $150 \mathrm{gm}$ grinded shrimp shell where $4 \% \mathrm{HCl} \& 5 \% \mathrm{HCl}$ were used as decalcifier. $500 \mathrm{ml}$ of $40 \% \mathrm{NaOH}$ was added to each sample \& were set into hot air oven at $120{ }^{\circ} \mathrm{C}$ for four hours. After heating the samples were filtered. The samples were neutralized by washing frequently with distilled water and litmus paper was used as indicator. $500 \mathrm{ml}$ of $2 \%$ acetic acid was added with sample, mixed properly by stirring and was kept for one hour to settle down. The aqua layer from the samples was separated by decantation. $500 \mathrm{ml}$ of $3 \% \mathrm{NaOH}$ was added to the aqua layer and watched carefully. A white precipitation settled down. Then the upper clear layer of liquid was separated from beakers. The precipitate was filtered, dried and collected as crude extracts. Chitosans extracted using $3 \%, 4 \%$ and $5 \% \mathrm{HCl}$ as decalcifiers were coded as Chito $\mathrm{A}$, Chito $\mathrm{B}$ and Chito $\mathrm{C}$ respectively. Percentage of yield was calculated for all the three extracts.

\section{Tests for organoleptic properties}

Physical state, color, odor and taste of the extract were observed.

\section{Determination of $\mathrm{pH}$}

$\mathrm{pH}$ was determined using Hanna microprocessor pH meter (Model: $\mathrm{pH} 210$ ).

\section{Test of insolubility}

Insolubility of the extract was tested in $1 \%(\mathrm{w} / \mathrm{w})$ acetic acid solution.

\section{Infrared spectral analysis}

Infrared spectrum of the extract was taken using FT-IR Shimadzu, Japan (Model: IR Prestize 21) and was compared with the standard chitosan IR spectrum (Cardenast et al., 2002).

\section{Brine shrimp lethality bioassay}

The cytotoxicity of the extracted chitosan samples was conducted following the procedure described by Meyer et al (1982). Vincristine, a well-known anticancer agent, was used as positive control. Log concentration and \% of mortality of brine shrimps were plotted and the $\mathrm{LC}_{50}$ values were calculated.

\section{DPPH free radical scavenging assay}

DPPH (2,2-Diphenyl-1-picrylhydrazyl) free radical scavenging activity of the extracted chitosan samples was determined following the procedure described by Gupta et al (2003). Quercetin was used as positive control. The inhibition curve was plotted and the $\mathrm{IC}_{50}$ values were determined.

\section{RESULTS AND DISCUSSION}

In the present work, $3.33 \%$ (Chito A), $4.01 \%$ (Chito B) and $3.45 \%$ w/w (Chito C) were extracted using $3 \%, 4 \%$ and $5 \% \mathrm{w} / \mathrm{v}$ concentrations of $\mathrm{HCl}$ as decalcifiers. The physicochemical properties of the extracts are presented in Table 1 . Appearance, odor, insolubility and $\mathrm{pH}$ of all the extracts were found to comply with the compendial specifications of pharmaceutical grade chitosan. The term chitosan does not refer to a uniquely defined compound; it merely refers to a family of copolymers with various fractions of acetylated units. It consists of two types of monomers: chitinmonomers and chitosan-monomers. Chitosan is a linear polysaccharide consisting of (1-4)-linked 2-amino-2-deoxy-b-D-glucopyranose. It has been proposed to define chitosan and chitin as soluble or insoluble in $0.1 \mathrm{M}$ acetic acid, respectively, or by degree of deacetylation. More than $20 \%$ of 
deacetylation is the proposed definition of chitosan (Roberts 1992b; Hoppe-Seiler 1994). Reference infrared spectrum of the standard chitosan (Figure 1) was compared with the IR spectrum of all the 3 chitosan extracts. A representative spectrum of Chito B (extracted by $4 \% \mathrm{HCl}$ using as decalcifier) is shown in Figure 2. Although the spectrum did not match completely with the standard one but few major peaks were similar and could be considered as a qualitative index of identification. For all the three samples, characteristic bands at $3689 \mathrm{~cm}^{-1}$ and $3640 \mathrm{~cm}^{-1}$ are attributed to $-\mathrm{NH}_{2}$ and $-\mathrm{OH}$ groups stretching respectively. There is a weak peak at $1794 \mathrm{~cm}^{-1}$ which indicates that the samples possess few chitin monomers and hence need further purification to obtain pure chitosan.

Table 1: Physicochemical characteristics of chitosan extracts from tiger shrimp's exoskeleton.

\begin{tabular}{|c|c|c|c|c|}
\hline Tests & $\begin{array}{l}\text { Specification of } \\
\text { Pharmaceutical grade }\end{array}$ & Chito A & Chito B & Chito C \\
\hline Appearance & White or yellow powder & Yellowish powder & Off-white powder & White powder \\
\hline Odor & No smell & No smell & No smell & No smell \\
\hline Insolubility & $\begin{array}{l}\text { Less than } 1 \% \text { insolubility in } \\
1 \% \text { acetic acid solution. }\end{array}$ & $<0.1 \%$ & $<0.1 \%$ & $<0.1 \%$ \\
\hline $\mathrm{pH}$ & $7-9$ & 7.1 & 7.5 & 7.5 \\
\hline
\end{tabular}

"Dalwoo corporation: A Natural Product from the Sea chitin, chitosan \& chitosan oligomer from crab shell specification of pharmaceutical grade chitosan.

The chitosan samples were found to be noncytotoxic when their cytotoxicity was evaluated by brine shrimp lethality bio assay (Table 2). The antioxidant properties of the extracted chitosan samples were determined by DPPH assay and the $\mathrm{IC}_{50}$ values of the samples are given in Table 3 . All the chitosan samples scavenged the DPPH free radical and dose dependent increase was observed. Park et al., (2004) suggested that chitosan might eliminate various free radicals by the action of nitrogen on the C-2 position of the chitosan. Xie et al., (2001) reported that the scavenging mechanism of chitosan is related to the fact the free radicals can react with the hydrogen ion from the ammonium ions $\left(\mathrm{NH}_{3}{ }^{+}\right)$to form a stable molecule. The $\mathrm{NH}_{3}{ }^{+}$has been formed by the amine group absorbing a hydrogen ion from the solution. Several studies (Yen et al., 2008; Kim and Thomas, 2007) have demonstrated that chitosan might have a potential as a free radical scavenger or an antioxidant.

Table 2: Cytotoxic effects of chitosan samples on brine shrimps

\begin{tabular}{cccc}
\hline \multicolumn{4}{c}{ IC $_{50}(\mu \mathrm{g} / \mathrm{mL})$} \\
\hline Chito A & Chito B & Chito C & Vincristine \\
$>110$ & $>100$ & $>108$ & $2 \pm 0.4$ \\
\hline
\end{tabular}

Table 3: DPPH radical scavenging activity of chitosan samples

\begin{tabular}{cccc}
\hline \multicolumn{4}{c}{ IC $_{\mathbf{5 0}}(\boldsymbol{\mu g} / \mathbf{m L})$} \\
\hline Chito A & Chito B & Chito C & Quercetin \\
$37 \pm 2$ & $35 \pm 1$ & $30 \pm 2$ & $15 \pm 2$ \\
\hline
\end{tabular}

\section{CONCLUSION}

This small scale extraction and characterization of chitosan from local shrimp shells reflect that there is an opportunity to extract chitosan from local sources and they might be used as a source of antioxidants, as a possible source of food supplement or ingredient or as excipient in the pharmaceutical industry.

\section{ACKNOWLEDGEMENT}

We express our thanks to Novartis Bangladesh Limited for providing laboratory facilities to take the IR spectrum of the chitosan samples.

\section{REFERENCES}

Chowdhury SS, Salahuddin M, Jamila M, Mazumder MEH. (2008) Infrared spectroscopic characterization of chitosan extracted from the exoskeleton of Scylla serrata. Primeasia Studies: 1 (In press) 
Cardenast G, Sanzanali J, Lucia H, Inoccentini M. (2002) Synthesis and characterization of chitosan-PHB blends. 2002. Boletín de la Sociedad Chilena de. Química. 47(4) Concepción dic.

Felt O, Furrer P, Mayer JM, Plazonnet B, Buri P, Gurny R. (1999) Topical use of chitosan in ophthalmology: tolerance assessment and evaluation of precorneal retention. Int $J$ Pharm.180:185-193.

Farkas V. (1990) Fungal cell walls: Their structure, biosynthesis and biotechnological aspects. Acta Biotechno.10: 225-238.

Fleet GH, Phaff HJ. (1981) Fungal glucans-structure and metabolism. Encycloped Plant Physio New Series, 13 (B): 416-440.

Gupta M, Mazumdar UK, Sivahkumar T, Vamsi MLM, Karki S, Sambathkumar R, Manikandar L. (2003) Antioxidant and anti-inflammatory activities of Acalypha fruticosa. Nig J Nat Prod Med. 7:25-29.

Hirano S. (1996) Chitin biotechnology applications. Biotechnol Annu Rev. 2: 237-258.

Hoppe-Seiler F. (1994) Chitin and chitosan. Ber Dtsch Chem Ges. 27: 3329-3331.

Lehr CM, Bouwstra JA, Schacht EH, Junginger HE. (1992) In vitro evaluation of mucoadhesive properties of chitosan and some other natural polymers. Int $J$ Pharm. 78: 43-48.

Lee HW, Park YS, Choi JW, Yi SY, Shin WS. (2003) Antidiabetic effects of chitosan oligosaccharides in neonatal streptozotocin-induced noninsulin-dependent diabetes Mellitus in Rats. Biol. Pharm. Bull. 26(8): 1100-1103.

Meyer BN, Ferringm NR, Puam JE, Lacobsen LB, Nichols DE, MeLaughlin, JL. (1982). Brine shrimp: a convenient general bioassay for active constituents. Planta Med. 45: 31-32.

Park PJ, Je JY, Kim, SW. (2004) Free radical scavenging activities of different deacetylated chitosans using an ESR spectrometer. Carbohydrate Polymer. 55: 17-22.

Paul W, Sharma CP. (2004) Chitosan and alginate wound dressings: A short review. Trends Biomater. Artif. Organs.18 (1):18-23.

Qing H, Qiang AO, Wang A, Gong Y, Zhao N, Zhang X. (2007) In Vitro Cytotoxicity and protein drug release properties of chitosan/heparin microspheres. Tsinghua Sci \& Tech. 12(4): 361365.

Roberts GAF. (1992) Structure of chitin and chitosan. In: Roberts GAF, ed. Chitin Chemistry. MacMillan, Houndmills. 1-53.

Roberts GAF (1992) Solubility and solution behaviour of chitin and chitosan. In: Roberts GAF, ed. Chitin Chemistry. MacMillan, Houndmills. 274-329.

Shahidi F, Abuzaytoun R. (2005) Chitin, chitosan, and co-products: chemistry, production, applications, and health effects. Adv Food Nutr. 49: 93.

Suzuki K, Mikami T, Okawa Y, Tokoro A, Suzuki S, Suzuki M. (1986) Antitumor effect of hexa-Nacetylchitohexaose and chitosexaose. Carbohyrate Res. 151: 403-408.

Suzuki K, Tokoro A, Okawa Y, Suzuki S, Suzuki M. (1986) Effect of N-acetyl-chitooligosaccharides on activation of phagocytes. Microbiol. \& Immunol. 30: 777-787.

Shon YH, Ha YM, Jeong TR, Kim CH, Nam KS. (2001) Modifying action of chitosan oligosaccharide on 2-amino-3,8-dimethylimidazo[4,5-f]quinoxaline (MelQx)-induced mutagenesis. J.Biochem. \& Mol. Biol. 34: 90-94.

Shi C, Zhu Y, Ran X, Wang M, Su Y, Cheng T. (2006) Therapeutic potential of chitosan and its derivatives in regenerative medicine. Surgical Research. 133 (2): ??

Xie W, Xu P, Liu Q. (2001) Antioxidant activity of water-soluble chitosan derivatives. Bioorg. \& Med. Chem. Lett. 11:1699-1701.

Yen MT, Yang JH, Mau JL. (2008) Antioxidant properties of chitosan from crab shells. Carbohydrate Polymers. 74: 840-844. 